\title{
Groundwater Recharge in Wisconsin-Annual Estimates for 1970-99 Using Streamflow Data
}

\author{
By Warren A. Gebert, John F. Walker, and Randall J. Hunt
}

\section{Introduction}

The groundwater component of streamflow is important because it is indicative of the sustained flow of a stream during dry periods, is often of better quality, and has a smaller range of temperatures, than surface contributions to streamflow. All three of these characteristics are important to the health of aquatic life in a stream. If recharge to the aquifers is to be preserved or enhanced, it is important to understand the present partitioning of total streamflow into base flow and stormflow. Additionally, an estimate of groundwater recharge is important for understanding the flows within a groundwater systeminformation important for water availability/sustainability or other assessments.

The U.S. Geological Survey operates numerous continuous-record streamflow-gaging stations (Hirsch and Norris, 2001), which can be used to provide estimates of average annual base flow. In addition to these continuous record sites, Gebert and others (2007) showed that having a few streamflow measurements in a basin can appreciably reduce the error in a base-flow estimate for that basin. Therefore, in addition to the continuous-record gaging stations, a substantial number of low-flow partial-record sites (6 to 15 discharge measurements) and miscellaneousmeasurement sites ( 1 to 3 discharge measurements) that were operated during 1964-90 throughout the State were included in this work to provide additional insight into spatial distribution of annual base flow and, in turn, groundwater recharge.

\section{How Were Estimates of Baseflow and Recharge Obtained?}

The methods used in this study are briefly summarized here; detailed descriptions of the data and methods are given in Gebert and others (2011). The recorded daily discharge at gaging stations can be separated into base flow and stormflow using the Base Flow Index (BFI) automated hydrograph separation approach (Institute of Hydrology, $1980 \mathrm{a}, \mathrm{b}$ ). A FORTRAN implementation of the BFI method (Wahl and Wahl, 1995) was applied to the daily streamflow at 123 gaging stations with continuous records for the 1970-99 period to determine the average annual base flow and total streamflow for each station. The resulting base-flow index, defined as the base flow divided by total streamflow, is presented in figure 1 .

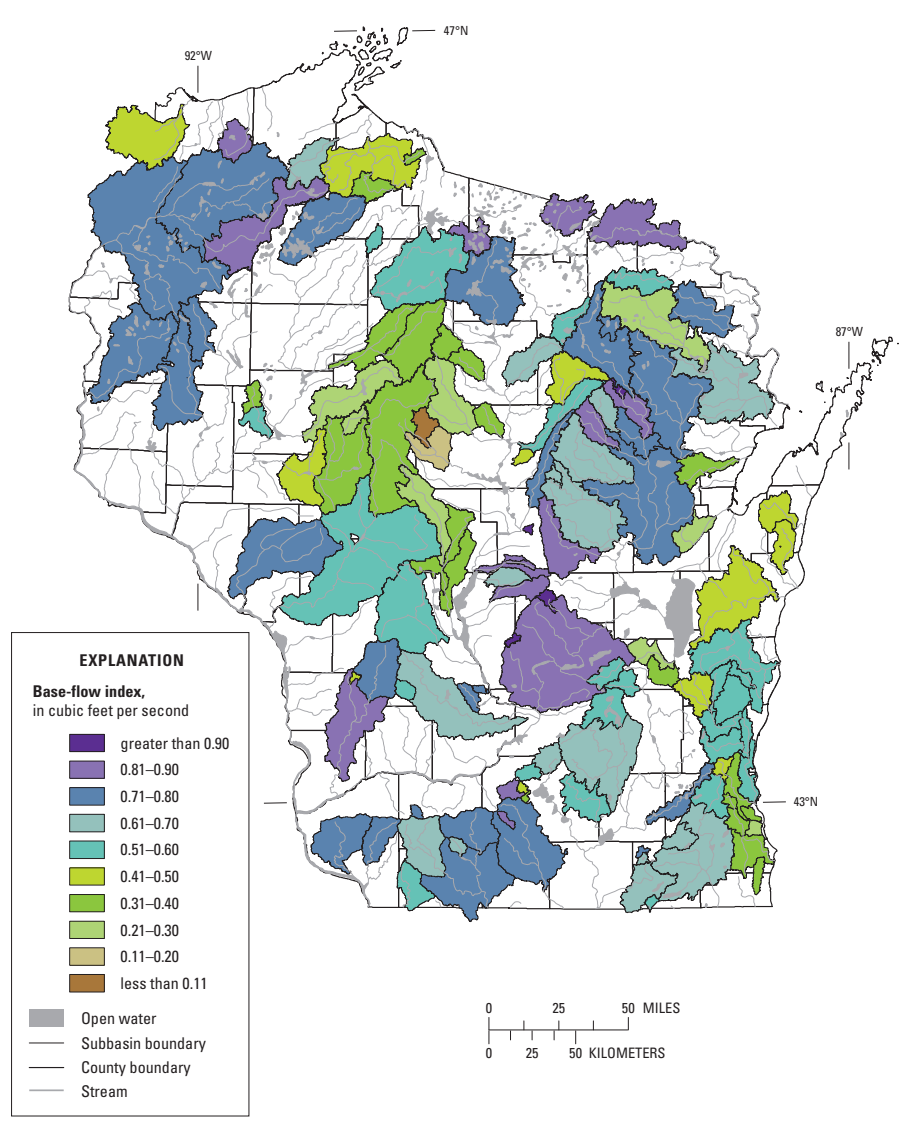

Figure 1. Spatial distribution of base-flow index, 1970-99, at streamflow-gaging stations in Wisconsin. 
Estimated average annual base flow can be divided by the basin area to express the base flow, in inches, over the basin. Assuming that the groundwater contributing area is the same as the surface-water drainage area, the long-term average base flow value, in inches, is a reasonable estimate for the recharge to the groundwater system. The resulting annual recharge values based on the 123 streamflow-gaging stations are shown in figure $2 \mathrm{~A}$.

For a low-flow partial-record site, estimates of average annual base flow can be obtained by relating a "snapshot" of streamflow at a location without a streamflow gaging station to daily discharge from a correlated gaging station (or "index station") recorded on the same day. In some cases the relation line between the two is not very good; thus, it provides an unreasonable estimate of annual base flow. For those cases, the statewide regression equation published by Gebert and others (2007) was used to estimate the average annual base flow.

For miscellaneous-measurement sites where only 1 to 3 measurements exist, insufficient discharge measurements preclude establishing a relation line with a nearby index station. As a surrogate, we used nearby low-flow partial-record sites and local knowledge of the regional hydrology to associate index sites with the miscellaneousmeasurement sites. With an associated index site, a discharge measurement made during low-flow conditions can be used to estimate average annual base flow using the statewide regression equation (Gebert and others, 2007). The resulting annual recharge values for the low-flow partial-record sites and the miscellaneous-measurement sites, collectively referred to as partial-record sites, are shown in figure $2 B$.

\section{What Was Learned from This Study?}

The results for continuous-record gaging stations (fig. 2A) and partial-record sites (fig. 2B) illustrate a wide range of estimated recharge rates for Wisconsin. Combining the areas covered by the two maps accounts for nearly 72 percent of the surface area of the State. The weighted average annual base flow for the State was 6.8 inches per year. The weighted average total streamflow for the State was 10.9 inches per year; thus, 62 percent of the annual total streamflow is comprised of base flow.

Generally, regional recharge rates exceeding 12 inches annually were considered unrealistic given the magnitude of precipitation and evapotranspiration across Wisconsin. These unrealistic rates were likely due to violations of the limiting assumptions (Gebert and others, 2011). In some cases, the groundwater and surface-water watershed boundaries did not align very closely, thus resulting in high values. In other cases, an exceptionally high value may be caused by error introduced by the method used to extrapolate base flow to basins without gaging stations. Gebert and others (2011) provides a likely cause for each basin with annual recharge in excess of 12 inches.
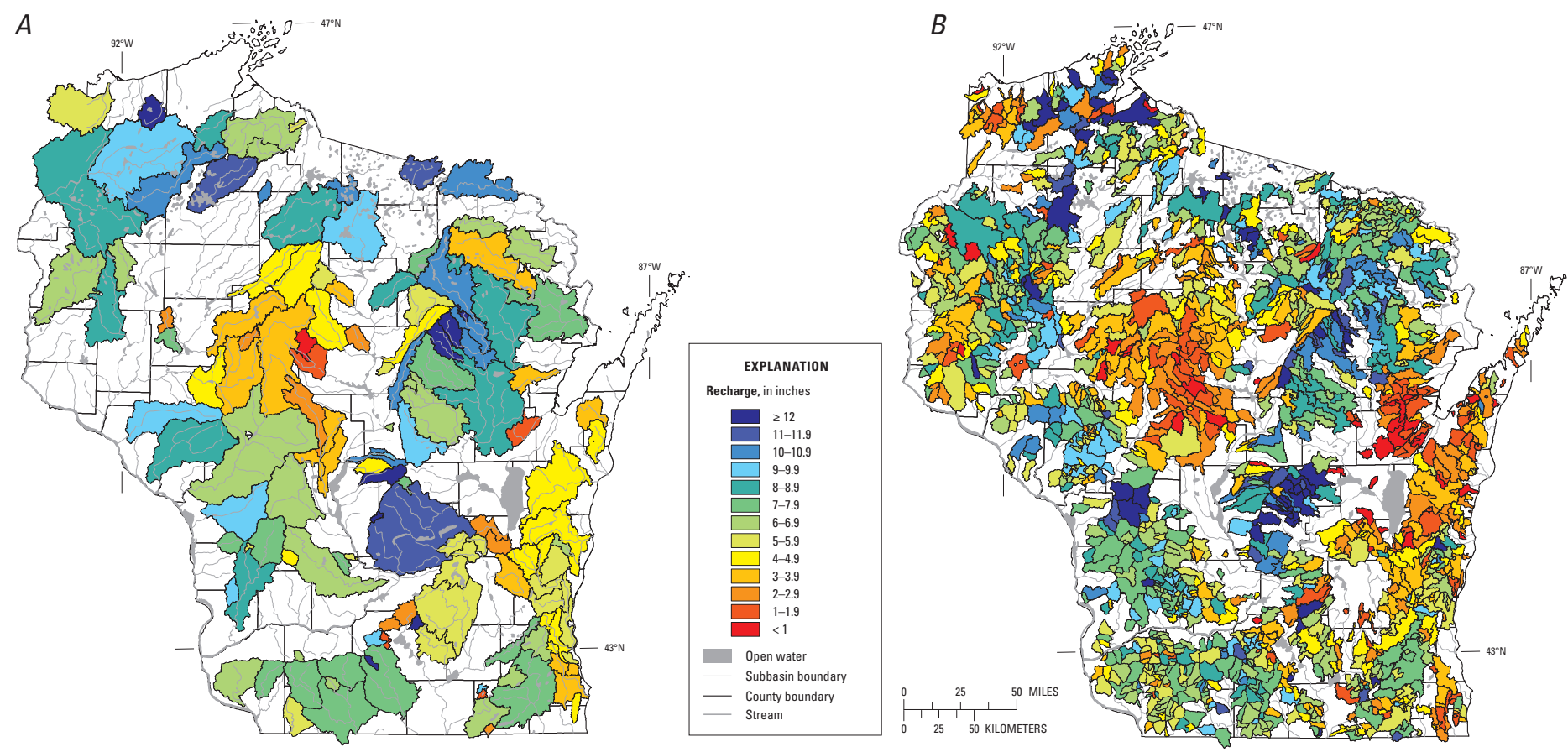

Figure 2. Spatial distribution of average annual groundwater recharge, 1970-99, on the basis of data from $A$, streamflow-gaging stations, and $B$, partial-record sites, in Wisconsin. 


\section{Has Annual Recharge Increased Since the Early 1900s?}

Recharge is not expected to be constant over time as both changes in climate and land use can affect how precipitation falling on the land surface is distributed between surface-water stormflow and recharge-derived base flow. The time period used to calculate base flow can affect the calculated recharge rate, because changes in streamflow and base flow directly affect estimates of recharge using the methods described herein. For example, Gebert and others (2007) examined temporal trends in base flow for the period of record for 22 streamflow-gaging stations in Wisconsin. A comparison of the average annual base flow for the period of record to the average annual base flow for the 1970-99 period is presented in table 1. Although base flow was calculated using the same technique, the values for the two periods differ by as much as 39 percent. Interestingly, the stations with differences of 10 percent or more all had statistically significant increasing trends in streamflow over the period of record (Gebert and others, 2007). The increasing trends in base flow are consistent with changes observed after 1970 in lakes, groundwater levels and streams around the State (Magnuson and others, 2003). Likewise, McCabe and Wolock (2002) found large-scale increases in annual minimum and median streamflows over large portions of the eastern U.S., indicating climate as a likely driver. Alternatively, Gebert and Krug (1996) suggest that changes in agricultural practices are the primary driver for these changes, thus basins that contain more agriculture by area are more likely to show increases in base flow over time. Although the exact relation among climate, land use, and recharge are still active areas of research, the results in table 1 underscore the need to match the time period used to estimate base flow and calculate recharge to the timeframe of the question being asked.

Table 1. Comparison of the average annual baseflow for the period of record to the 1970-99 period.

[Bold values indicate statistically significant trends in baseflow for the period of record (Gebert and others, 2007)]

\begin{tabular}{|c|c|c|c|c|c|c|}
\hline \multirow{2}{*}{$\begin{array}{l}\text { Station } \\
\text { number }\end{array}$} & \multirow[t]{2}{*}{ Station name } & \multirow{2}{*}{$\begin{array}{l}\text { Period of } \\
\text { record }\end{array}$} & \multirow{2}{*}{$\begin{array}{l}\text { Length of } \\
\text { record } \\
\text { (years) }\end{array}$} & \multicolumn{3}{|c|}{$\begin{array}{l}\text { Average annual baseflow } \\
\text { (cubic feet per second) }\end{array}$} \\
\hline & & & & Full record & 1970-99 & Percent difference \\
\hline 04025500 & Bois Brule River - Brule & $1943-99$ & 57 & 149 & 152 & 2.0 \\
\hline 04063700 & Popple River - Fence & 1964-99 & 36 & 69.7 & 68.5 & -1.7 \\
\hline 04069500 & Peshtigo River - Peshtigo & 1954-99 & 46 & 566 & 604 & 6.7 \\
\hline 04073500 & Fox River - Berlin & 1900-99 & 100 & 941 & 1,130 & 20.1 \\
\hline 04074950 & Wolf River - Langlade & 1967-99 & 33 & 349 & 351 & 6 \\
\hline 04086000 & Sheboygan River - Sheboygan & 1917-99 & 83 & 122 & 146 & 19.7 \\
\hline 04087000 & Milwaukee River - Milwaukee & 1915-99 & 85 & 209 & 290 & 38.8 \\
\hline 05362000 & Jump River - Sheldon & $1916-98$ & 83 & 173 & 190 & 9.8 \\
\hline 05368000 & Hay River - Wheeler & $1951-98$ & 48 & 232 & 263 & 13.4 \\
\hline 05379500 & Trempealeau River - Dodge & 1915-99 & 85 & 327 & 404 & 23.5 \\
\hline 05381000 & Black River - Neillsville & 1906-99 & 94 & 162 & 201 & 24.1 \\
\hline 05394500 & Prairie River - Merrill & 1915-99 & 85 & 115 & 114 & -.9 \\
\hline 05397500 & Eau Claire River - Kelly & 1915-99 & 85 & 127 & 134 & 5.5 \\
\hline 05399500 & Big Eau Pleine River - Stratford & $1915-99$ & 85 & 30 & 32 & 6.7 \\
\hline 05405000 & Baraboo River - Baraboo & 1915-99 & 85 & 219 & 271 & 23.7 \\
\hline 05406500 & Black Earth Creek - Black Earth & $1955-98$ & 44 & 29.1 & 32.2 & 10.7 \\
\hline 05408000 & Kickapoo River - LaFarge & 1939-99 & 61 & 123 & 144 & 17.1 \\
\hline 05413500 & Grant River - Burton & 1935-99 & 65 & 111 & 137 & 23.4 \\
\hline 05414000 & Platte River - Rockville & 1935-99 & 65 & 65.1 & 78.5 & 20.6 \\
\hline 05426000 & Crawfish River - Milford & 1932-99 & 68 & 229 & 271 & 18.3 \\
\hline 05432500 & Pecatonica River - Darlington & $1940-99$ & 60 & 121 & 143 & 18.2 \\
\hline 05436500 & Sugar River - Brodhead & 1915-99 & 85 & 234 & 297 & 26.9 \\
\hline
\end{tabular}


The difference in drainage area for continuous-record streamflow-gaging stations (average 305 square miles) and partial-record sites (average 50 square miles) can be used to illustrate the effect of basin scale on spatial variability of recharge. Values for large basins will likely be less variable than values for small basins, because the value reported for a particular type of site represents an average over the entire drainage area. Thus, one would expect more variability for the partial-record sites (fig. $2 B$ ) than the gaging stations, which generally represent large basins (fig. $2 A$ ). This is particularly evident when comparing a value for a gaging station to the values for partial-record sites that are contained within the gaging station drainage boundary. For example, there are several gaging stations in the northwest part of the State that have a number of partial-record sites nested within the drainage boundary for each gaging station. The variability of the values for the smaller nested basins is appreciably higher than for the larger gaging stations that contain the partialrecord sites.

From the results shown in figure 2, general patterns can be seen in the State. The northern forested portion of the State contains some of the highest values, due in part to highly permeable sandy soils, a thick transmissive aquifer, and somewhat lower evapotranspiration. Fairly high values also are found in the central portion of the State (east of the Wisconsin River). This portion of the State, referred to as the Central Sand Plains, contains fairly thick highly conductive sandy sediments and a transmissive aquifer. These basin properties, along with the area's flat terrain, facilitate the infiltration of water into the groundwater system rather than becoming stormflow or evapotranspiration. There is a fairly uniform distribution of recharge in the southwest portion of the State, often referred to as the "Driftless Area," with a predominant range from roughly 6 to 9 inches per year. This is consistent with the relatively uniform underlying geology in the Driftless Area. There are somewhat low values in the central portion west of the Wisconsin River, where the aquifers are thin and surficial soils have low permeability. These factors are expected to result in less aquifer storage and increased surface runoff. This portion of the State also has some of the lowest base flow index values (fig. 1), which also indicates that water not infiltrated and stored in the aquifer contributes to streamflow as surface runoff. Low values also are evident along the southern border of Lake Superior and the western edge of Lake Michigan, likely the result of clayey surficial soils that inhibit infiltration.

\section{References Cited}

Gebert, W.A., and Krug, W.R., 1996, Streamflow trends in Wisconsin's driftless area: Journal of the American Water Resources Association, v. 32, no. 4, p. 733-744.

Gebert, W.A., Radloff, M.J., Considine, E.J., and Kennedy, J.L., 2007, Use of streamflow data to estimate base flow/groundwater recharge for Wisconsin: Journal of the American Water Resources Association, v. 43, no. 1, p. 220-236.

Gebert, W.A., Walker, J.F., and Kennedy, J.L., 2011, Estimating 1970-99 average annual groundwater recharge in Wisconsin using streamflow data: U.S. Geological Survey Open-File Report 2009-1210, 17 p. plus appendixes..

Hirsch, R.M., and Norris, J.M., 2001, National streamflow information program-Implementation plan and progress report: U.S. Geological Survey Fact Sheet FS-048-01, $6 \mathrm{p}$.

Institute of Hydrology, 1980a, Low flow studies: Wallingford, Oxon, United Kingdom, Report No. 1, 41 p.

Institute of Hydrology, 1980b, Low flow studies: Wallingford, Oxon, United Kingdom, Report No. 3, p. 12-19.

Magnuson, J.J., Krohelski, J.T., Kunkel, K.E., and Robertson, D.M., 2003, Wisconsin's waters and climatehistorical changes and possible futures, in Meine, C., ed., Wisconsin's waters - a confluence of perspectives: Madison, Wis., Wisconsin Academy of Sciences Arts and Letters, p. 23-36.

McCabe, G.J., and Wolock, D.W., 2002, A step increase in streamflow in the conterminous United States: Geophysical Research Letters, v. 29, no. 24, p. 2185-2188.

Wahl, K.L. and Wahl, T.L., 1995, Determining the flow of Comal Springs at Braunfels, Texas, in Texas Water '95: August 16-17, 1995, San Antonio, Tex., American Society of Civil Engineers, p. 77-86.

\section{For more information, please contact:}

Center Director

USGS Wisconsin Water Science Center

8505 Research Way

Middleton, WI 53562

(608) 828-9901

http://wi.water.usgs.gov 